\title{
T-Cell Variant of Classical Hodgkin's Lymphoma with Nodal and Cutaneous Manifestations Demonstrated by Single-Cell Polymerase Chain Reaction
}

\author{
Klaus Willenbrock, Ryo Ichinohasama, Marshall E. Kadin, Ikuo Miura, Tadashi Terui, \\ Kuniaki Meguro, Osamu Fukuhara, John F. DeCoteau, and Martin-Leo Hansmann
}

Senckenberg Institute of Pathology (KW, M-LH), University of Frankfurt, Frankfurt am Main, Germany; Department of Oral Pathology (RI), Tohoku University School of Dentistry, and Department of Dermatology (TT) and Second Department of Internal Medicine (KM, OF), Tohoku University School of Medicine, Sendai, and Department of Internal Medicine 3 (IM), Akita University, Akita, Japan; Department of Pathology (MEK), Beth Israel Deaconess Hospital and Harvard Medical School, Boston, Massachusetts; and Department of Pathology (JFD), Royal University Hospital, University of Saskatchewan, Saskatoon, Canada

SUMMARY: The atypical cells of $\mathrm{CD} 30^{+}$cutaneous lymphoproliferative disorders (CD30CLD) are commonly of T-cell origin and frequently have a similar morphology as Hodgkin or Reed-Sternberg cells of Hodgkin's lymphoma (HL). HL is one of the tumors associated with CD30CLD. Although most studies support a B-cell derivation of the tumor cells in HL, recently a few cases of classical HL with T-cell genotype have been reported. We report a patient who presented with CD30CLD whose lymph nodes showed classical HL of mixed cellularity subtype at presentation. By single-cell PCR, the same clonal gene rearrangements of the T cell receptor- $\beta$ gene locus could be assigned to the $\mathrm{CD} 30^{+}$and $\mathrm{CD} 15^{+}$cells of both skin and lymph node. In a lymph node biopsy specimen taken in relapse after several courses of chemotherapy, the $\mathrm{CD} 30^{+}$tumor cells were abundant. The $\mathrm{T}$ cell-derived tumor cells displayed aberrant expression of the Pax-5 gene in all specimens. A common clonal origin of both CD30CLD and HL of the lymph node in the patient presented here suggests that HL with T-cell genotype exists in association with CD30CLD as well as in sporadic cases and may share clonal origin with the skin tumor. (Lab Invest 2002, 82:1103-1109).

$H$ odgkin's lymphoma (HL) is characterized by relatively few atypical tumor cells surrounded by a polymorphous inflammatory infiltrate comprised of varying proportions of small lymphocytes, plasma cells, eosinophils, and histiocytes (Lukes et al, 1966). The origin of these Hodgkin and Reed-Sternberg cells (HRS cells) has been a longstanding mystery. Expression of lymphocyte-associated antigens suggested a lymphoid origin of HRS cells. B- or T-cell derivation has been unclear, however, because the scarcity of tumor cells in the tissue did not allow the issue to be evaluated by antigen receptor gene rearrangement studies using DNA extracted from whole tissue specimens. An antigen receptor gene rearrangement could be demonstrated on DNA extracted from whole tissue in only a few cases with many HRS cells (Weiss et al, 1986a). The development of micromanipulation and single-target gene amplification provided a useful tool

Received December 4, 2001.

This study was supported in part by a grant from the Ministry of Health and Welfare, Japan (No. 11-8, 2000) and the Deutsche Krebshilfe, Dr. Mildred Scheel Stiftung.

Address reprint requests to: Dr. Klaus Willenbrock, Senckenbergisches Institut für Pathologie, Theodor Stern Kai 7, 60590 Frankfurt am Main, Germany. E-mail: Willenbrock@em.uni-frankfurt.de to resolve this problem. By amplification of rearranged genes encoding the antigen binding site, immunoglobulin genes for $B$ cells and $T$ cell receptor (TCR) genes for $T$ cells, the lineage derivation of single micromanipulated HRS cells could be established (Küppers et al, 1994). The vast majority of cases of classical $\mathrm{HL}$ studied by this technique revealed a B-cell derivation of HRS cells (Kanzler et al, 1996; Küppers et al, 1999; Marafioti et al, 2000; Müschen et al, 2001).

A T-lineage derivation of HRS cells has been suggested in a few cases of classical HL associated with cutaneous T-cell lymphoma (Davis et al, 1992; Kadin et al, 1988, 2001). However, the cases reported were not studied on a single-cell level; thus, the T-cell nature of HRS cells was not formally proven. Typical T-cell proteins such as granzyme $B$, perforin, and TIA-1 found by immunostaining in HRS cells of some cases of classical HL suggested the possible existence of T cell-derived HL (Felgar et al, 1997; Krenacs et al, 1997). A clonal TCR- $\beta$ gene rearrangement was found in one of three such cases recently studied by single-cell PCR, demonstrating the derivation of these HRS cells from a T cell (Müschen et al, 2000). Subsequently, in a series of $13 \mathrm{~T}$-cell marker-positive HL, two cases were reported with clonal TCR- $\gamma$ gene rearrangements (Seitz et al, 2000). 
In the case presented here, classical HL is associated with $\mathrm{CD}^{+} \mathrm{O}^{+}$cutaneous lymphoproliferative disorder (CD30CLD). Clonal TCR gene rearrangements could be detected in both skin and lymph node specimens and assigned to the HRS cells by micromanipulation and single-cell PCR.

\section{Results}

\section{Histologic and Immunohistochemical Examination}

The skin specimen showed a subepidermal infiltrate of large atypical cells with bizarre nuclei and prominent nucleoli (Fig. 1A). These cells were found in sheets, and some were multinucleated cells with characteristics of Reed-Sternberg cells (Fig. 1B). These atypical cells expressed CD30 and CD15 (Fig. 1C) and the T-cell marker $\beta$ F1 (Fig. 1D). The surrounding cells were mostly small $\beta \mathrm{F} 1^{+} \mathrm{T}$ lymphocytes. Because of the growth pattern of the large $\mathrm{CD}^{+}{ }^{+}$cells, the diagnosis of CD30CLD was made on the skin specimen.

The primary lymph node biopsy specimen taken at the same time as the skin biopsy specimen revealed an effaced architecture with an infiltrate of scattered classical HRS cells, often multinucleated, with huge inclusion-like nucleoli surrounded by many lymphocytes, most of which were $\beta \mathrm{F} 1^{+} \mathrm{T}$ cells, and a varying admixture of histiocytes and plasma cells (Fig. 1E). Occasional HRS cells showed apoptosis (so-called mummified cells). Some of the HRS cells occurred in lacunar spaces reminiscent of nodular sclerosing type of HL, but no coarse collagen bands were found, so the consensus diagnosis was mixed cellularity type $\mathrm{HL}$ (Fig. 1F). This diagnosis was supported by the immunoprofile of the HRS cells (Table 1 and Fig. 1G). HRS cells of the lymph were negative for $\beta \mathrm{F} 1$.

At relapse, the lymph node specimen was replete with large $\mathrm{CD}^{+}{ }^{+}$cells occurring in sheets. Only a few small lymphocytes were found interspersed between the tumor cells (Fig. 1H). Immunohistochemical markers were identical to those of the previous biopsy specimens (Table 1).

\section{Single-Cell Analysis}

For micromanipulation, areas showing infiltration by HRS cells were identified in CD30-stained sections of both skin and lymph node specimens with HL. Single $\mathrm{CD}^{+}{ }^{+}$and $\mathrm{CD}^{+} 5^{+} \mathrm{HRS}$ cells of the lymph node, $\mathrm{CD}^{+}{ }^{+} \mathrm{HRS}$ cells of the skin, and small $\beta \mathrm{F} 1^{+}$cells of both specimens were micromanipulated from adjacent sections and transferred into PCR tubes. TCR- $\beta$ gene rearrangements were amplified using mixtures of $\mathrm{V} \beta$ family-specific and $\mathrm{J} \beta$-specific primers and sequenced. Single CD20 ${ }^{+}$cells micromanipulated from sections of the skin specimen, aliquots of the buffer covering the sections during the micromanipulation procedure ("buffer samples"), and PCR tubes containing PCR reagents but no cell ("water controls") served as negative controls. Single $\mathrm{CD}^{+\alpha \beta+} \mathrm{T}$ cells from peripheral blood of a healthy donor were sorted by flow cytometry into PCR tubes and analyzed in parallel to control for the efficiency of single target amplification of TCR- $\beta$ gene rearrangements.

Table 2 shows a summary of the single-cell PCR results. Thirty percent of the micromanipulated cells yielded a specific PCR product. None of the negative control samples, but four (80\%) of five of the sorted single $\mathrm{CD}^{+\alpha \beta} \mathrm{TCR}^{+} \mathrm{T}$ cells, yielded a specific product, demonstrating the high efficiency of the singlecell PCR. The rearrangements obtained from sorted peripheral blood $\mathrm{T}$ cells were all unrelated to each other and to the rearrangements amplified from micromanipulated cells.

Identical clonal TCR- $\beta$ gene rearrangements were obtained from 13 of $32 \mathrm{CD}^{+} 0^{+}$and 5 of $16 \mathrm{CD}^{+} 5^{+}$ HRS cells of the lymph node and 8 of $16 \mathrm{CD}^{+} 0^{+} \mathrm{HRS}$ cells of the skin (Table 2). On both alleles of the tumor clone, the same $\mathrm{V}$ gene segment was rearranged, both to different $\mathrm{J}$ segments (BV2S1-J2.1, BV2S1-J1.4). One of these rearrangements (BV2S1-J1.4) was rearranged out of frame and, thus, was nonfunctional. The rearranged $\mathrm{V}$ and $\mathrm{J}$ segments displayed complete sequence identity to the respective germline sequences. The clonal gene rearrangements of the tumor cells were also amplified from three small $\beta \mathrm{F} 1^{+} \mathrm{T}$ cells of the skin. Eight further functional gene rearrangements amplified from small $\beta \mathrm{F} 1^{+} \mathrm{T}$ cells of the skin were unique to each other and to those of the tumor. Seven in-frame amplificates obtained from small $\beta \mathrm{F} 1^{+} \mathrm{T}$ cells of the lymph node specimen were distinct from those of the tumor clone and to each other. No specific gene rearrangement was obtained for small $\mathrm{CD}_{20}{ }^{+}$cells micromanipulated from the skin or from water and buffer probes coamplified to control for contamination artifacts.

\section{Discussion}

An association of HL with CD30CLD has been reported frequently (Bekkenk et al, 2000; Davis et al, 1992; Kaudewitz et al, 1990; Sanchez et al, 1983). The large atypical cells, especially of lymphomatoid papulosis, share morphologic and immunophenotypic similarities with HRS cells of HL. In lymphomatoid papulosis and other variants of CD30CLD, these atypical cells derive from activated $\mathrm{T}$ helper cells (Kadin et al, 1985). The detection of clonal T-cell populations in lymphomatoid papulosis pointed toward a lymphoproliferative origin of this disease (Kadin et al, 1987; Weiss et al, 1986b). It is on this basis that a common origin of HRS cells in some cases of $\mathrm{HL}$ and $\mathrm{CD} 30^{+}$ atypical cells in CD30CLD from activated $T$ helper cells was proposed (Kadin, 1985).

In this report, we present a case of CD30CLD in which enlarged axillary lymph nodes found at presentation showed characteristic features of classical HL of mixed cellularity type morphologically and immunohistochemically. In the lymph node, the $\mathrm{CD}^{+} 0^{+}$and $\mathrm{CD}^{+} 5^{+}$cells dominating the cellular infiltrate in the skin were only a minor component of the tumor. The surrounding cells in the lymph node displayed the typical polymorphic picture of classical HL. In the skin 

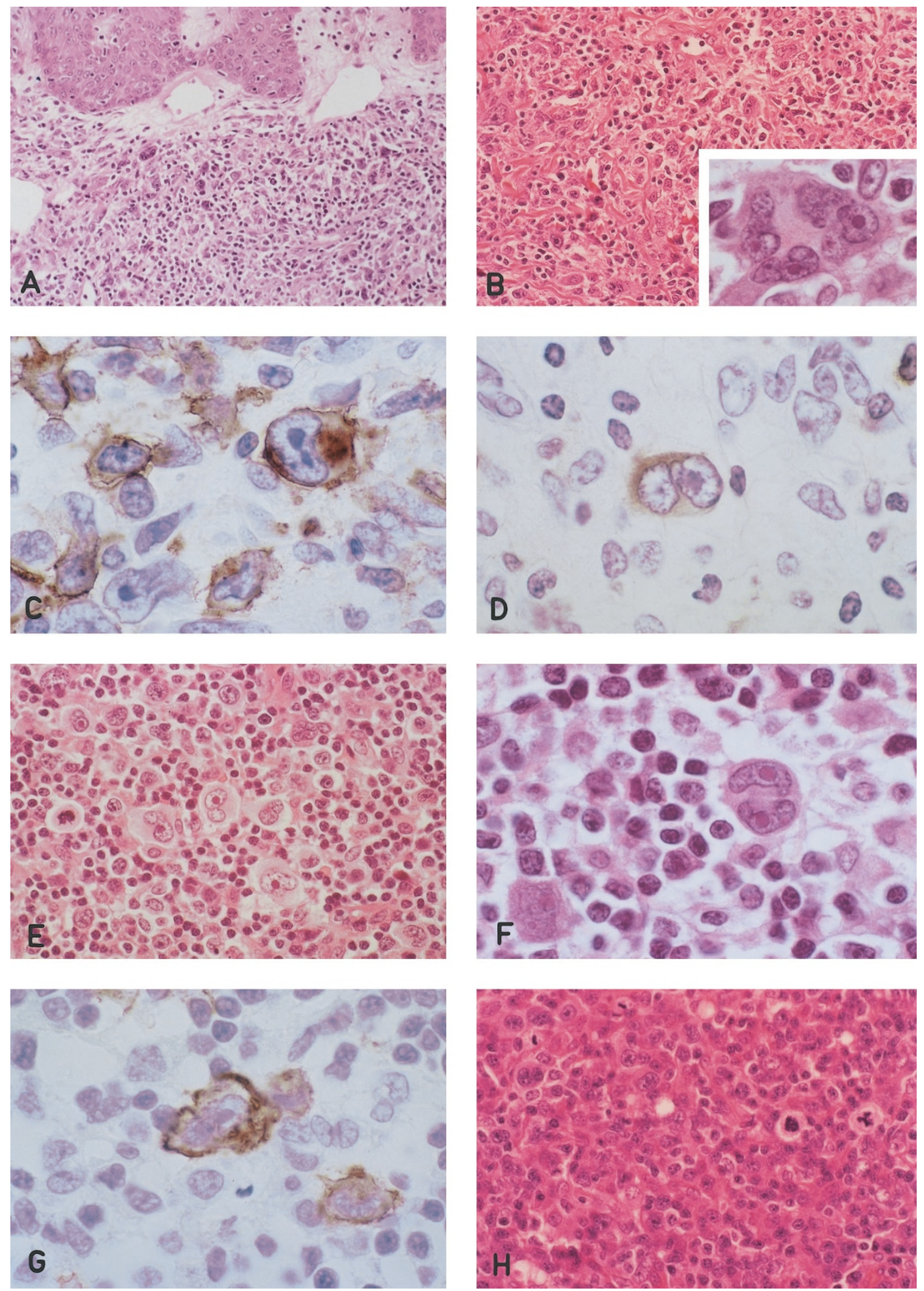

\section{Figure 1.}

Histologic and immunohistochemical stainings of skin and lymph node specimens. A, CD30 ${ }^{+}$cutaneous lymphoproliferative disorder with infiltrate of large cells with pleomorphic nuclei. B, Lymphoma cells in the skin specimen at primary diagnosis. Inset shows a multinucleated cell with characteristics of a Reed-Sternberg (RS) cell. C, CD15 ${ }^{+}$cell of the skin tumor (LeuM1). D, Large lymphoid cell of the skin expressing T cell receptor- $\beta(\beta F 1)$. E, Hodgkin's lymphoma of the lymph node at primary manifestation with RS cells and lacunar cells surrounded by a polymorphic cellular infiltrate. F, RS cell in the lymph node. G, CD15 ${ }^{+}$immunostaining in Hodgkin cells, lymph node, primary manifestation (LeuM1). H, Infiltrate of numerous large lymphoid cells in the lymph node in relapse. 
Table 1. Immunohistochemical Staining and In Situ Hybridization of HRS- and Tumor Cells of Skin and Lymph Node Specimens

\begin{tabular}{lccc}
\hline Staining & Skin tumor & LN (primary) & LN (relapse) \\
\hline CD3 & - & - & - \\
CD5 & - & - & - \\
CD10 & - & - & - \\
CD15 & + & + & + \\
CD20 & - & - & - \\
CD30 & + & + & + \\
CD45R0 & $-/+$ (very weak) & + & + \\
CD56 & - & - & - \\
EMA & + & + (weak) \\
Fascin & $>+$ (strong) & - & + (weak) \\
$\beta$ F1 & + & - & - \\
Perforin & - & + (weak) \\
BSAP & + (weak) & - & - \\
Alk1 (p80) & - & - & + (weak) \\
EBER & - & - & - \\
LMPI & - & nd
\end{tabular}

BSAP, B cell-specific activator protein; EBER, Epstein-Barr virus-encoded RNA; LN, lymph node; nd, not done.

Table 2. Single-Cell PCR Results of Skin and Lymph Node Specimens at Primary Presentation

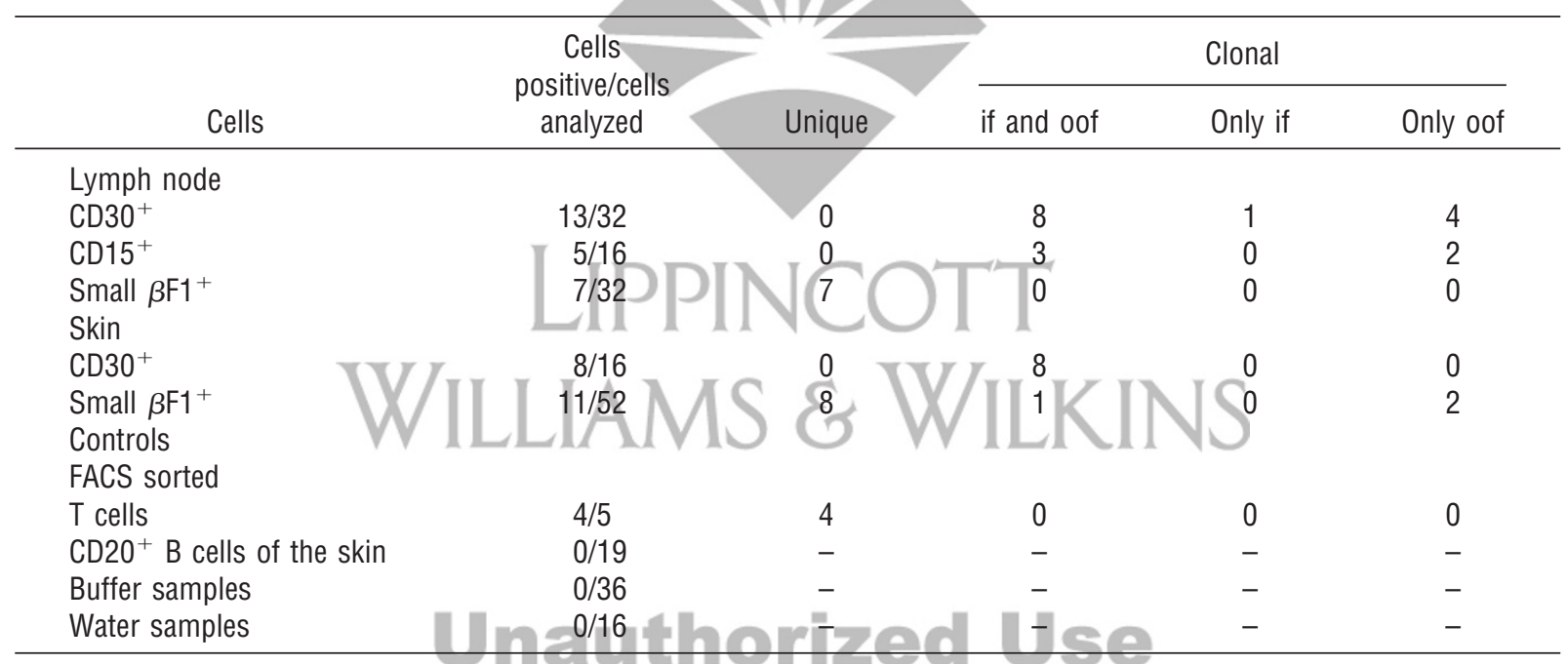

Two rearrangements, one in-frame (if) and one out-of-frame (oof), were amplified from the clone. From some isolated cells, both rearrangements were amplified; and from other cells, either in-frame or out-of-frame rearrangements were amplified, as indicated.

mostly small lymphocytes were found around the large atypical cells, the majority of which were $\beta \mathrm{F}^{+}$.

By micromanipulation and single-target gene amplification, identical clonal TCR- $\beta$ gene rearrangements could be assigned to the $\mathrm{CD} 30^{+} / \mathrm{CD} 15^{+}$cells in both skin and lymph node. Detection of identical gene rearrangements in three small $\beta \mathrm{F} 1^{+} \mathrm{T}$ cells of the skin suggest that they are morphologic precursors to the tumor cells. Gene rearrangements of the surrounding $T$ cells in the lymph node were polyclonal and unrelated to those of the tumor, as it is typically found in $\mathrm{HL}$ (Meggetto et al, 1994; Roers et al, 1998; Willenbrock et al, 2000). Thus, the same tumor clone that probably originated from activated small T cells in the skin and developed into CD30CLD, which had been growing untreated for a year, gave rise to the tumor cells of classical $\mathrm{HL}$ in the lymph node.
Expression of the transcription factor B cell-specific activator protein (BSAP; encoded by the Pax-5 gene) has recently been reported to be specific for B-cell lineage (Nutt et al, 1999). In HRS cells of classical HL, the detection of BSAP by immunostaining ranged from 5 of 14 cases (Krenacs et al, 1998) to 28 of 31 cases (Foss et al, 1999). In the latter report, weak positivity for BSAP in a proportion of HRS cells was interpreted as evidence for the B-lineage derivation of $\mathrm{HL}$. In contrast to the HLs of T cell genotype reported in the literature (Seitz et al, 2000), the case presented here displayed weak positivity for BSAP in the nucleus of some HRS cells in all specimens. Surrounding B cells were strongly positive. We conclude that weak positivity of HRS cells for BSAP by immunohistochemistry does not sufficiently allow determination of the B-cell lineage derivation of the lymphoma. 
CD30CLD, which includes clinically benign disorders such as lymphomatoid papulosis and frankly malignant $\mathrm{CD} 30^{+}$large T-cell lymphomas and borderline cases, is a heterogeneous group of diseases that may also include primary cutaneous $\mathrm{HL}$ (Willemze et al, 1997). Although immunostaining of tumor cells for CD15 is only seen in a few cases of CD30 large T-cell lymphomas (de Bruin et al, 1993; Vergier et al, 1998), the skin tumor of the case presented here cannot be diagnosed strictly as primary cutaneous HL. General agreement exists that primary cutaneous HL should be diagnosed only when there is no lymphadenopathy for 6 months after the primary diagnosis (Kadin, 1991). Cutaneous involvement of primary nodal classical HL seems highly unlikely in this case because it usually occurs late and in widespread Stage IV disease and is associated with fatal outcome (White and Patterson, 1985); however, the skin tumor might still represent primary cutaneous $\mathrm{HL}$, because it appeared clinically 1 year before the first lymph node biopsy was performed.

In the relapse, after several cycles of polychemotherapy and radiation, the tumor infiltrate in the lymph node had the appearance of a $\mathrm{CD}^{+} 0^{+}$large cell lymphoma. Immunohistochemical markers were identical to those of the previous biopsy specimens. Recognizing that all sites of disease are clonally related, this specimen might be interpreted as lymphocytedepleted HL or it might represent a subclone that acquired additional transforming events in the course of chemotherapy.

We conclude that classical $\mathrm{HL}$ in association with CD30CLD may share clonal origin and T-cell genotype with the cutaneous T-cell lymphoproliferative disorder and, thus, represent a special variant of $\mathrm{HL}$, which is most frequently of B-cell origin. $L D U N$

\section{Materials and Methods}

\section{Morphologic and Immunohistochemical Examination}

CD30CLD was diagnosed on a skin lesion of $8 \times 4.5$ $\mathrm{cm}$ on the abdomen of a 50-year-old Japanese woman. The skin tumor had been growing untreated for a year. Lymph nodes were then removed from the right axilla, and a diagnosis of classical $\mathrm{HL}$, mixed cellularity subtype, was made independently by the following expert hematopathologists: Dr. Taizan Suchi, Dr. Shigeo Nakamura (Aichi Cancer Center Hospital), Dr. Jun-ichi Tamaru (Saitama Medical College Hospital), Dr. Shigeo Mori (Medical Research Institute, Tokyo University), and some of the authors (RI, MEK, JFD, M-LH). Upon rebiopsy of a right axillary lymph node in February 2000, after several courses of polychemotherapy and radiation, abundant $\mathrm{CD} \mathrm{O}^{+}$large tumor cells were found.

For immunohistochemical staining of all specimens, thinly cut tissue fragments were fixed in PBS with 1\% paraformaldehyde by microwave for 25 seconds and washed in PBS with $20 \%$ sucrose at room temperature overnight, then quickly frozen in acetone at $-70^{\circ} \mathrm{C}$. Frozen and trypsin-treated paraffin-embedded sections were stained with the following monoclonal antibodies: CD3, CD10, CD20, CD30, EMA, Fascin, Perforin, Alk1 (p80), LMP1 (all from Dako, Glostrup, Denmark), CD5, CD15, CD45R0 (all from Becton Dickinson, Mountain View, California), CD56 (Novocastra, Newcastle upon Trent, United Kingdom), $\beta \mathrm{F} 1$ (T Cell Diagnostics, Cambridge, United Kingdom), BSAP (Santa Cruz Biotechnology, Santa Cruz, California); staining was followed by the avidin-biotin peroxidase method for development. For BSAP staining, sections were pretreated by highpressure cooking in $10 \mathrm{mmol}$ citrate buffer, $\mathrm{pH} 6$, for 2 minutes.

Epstein-Barr virus genome was detected by in situ hybridization using digoxigenin-labeled Epstein-Barr virus-encoded RNA sense and antisense probes, which were incubated overnight with deparaffinized sections followed by stringent washings and visualization with alkaline phosphatase.

\section{Single-Cell PCR}

Immunohistochemical staining of frozen tissue sections was performed as described (Küppers et al, 1993), using monoclonal antibodies against CD30 (BerH2; Dako), CD15 (C3D-1; Dako), CD20 (L26; Dako), and TCR- $\alpha / \beta$ ( $\beta \mathrm{F} 1 ;$ T cell Diagnostics). Alkaline phosphatase was developed using Fast Red TR (Sigma, Deisenhofen, Germany). Single cells were extracted by micromanipulation from skin and lymph node specimens as described (Küppers et al, 1993) and transferred into PCR tubes.

Amplification of TCR $V \beta$ gene rearrangements was performed as described (Roers et al, 1998). Briefly, micromanipulated cells were incubated with proteinase K. A first round of PCR was performed in the same tube using a mixture of $25 \vee \beta$ family-specific and 7 $\mathrm{J} \beta$-specific primers. A second round of amplification was performed in 96-well plates adding $1 \mu \mathrm{l}$ of the first-round reaction to each of 8 reaction mixtures, each containing 2 to 5 of the $25 \mathrm{~V} \beta$ primers and a mixture of internal $\mathrm{J} \beta$ primers.

PCR products were directly sequenced using the Ready Reaction dRhodamine cycle sequencing kit (Perkin Elmer, Foster City, California) as recommended by the manufacturer. Sequences of $\mathrm{V} \beta$ gene rearrangements were deposited in the European Molecular Laboratory database under accession numbers AJ406150-AJ406167.

\section{Acknowledgements}

The authors are grateful to Mr. Ralf Küppers for careful review of the manuscript and Mrs. Ekaterini Hadzoglou, Mr. Toshikazu Yamaguchi, Mr. Mitsuru Inoue, Mr. Yoshito Tsurukubo, Mr. Satoshi Iwai, and Mr. Atsushi Abe for technical assistance.

\section{References}

Bekkenk MW, Geelen FAMJ, van Voorst Vader PC, Heule F, Geerts ML, van Vloten WA, Meijer JLM, and Willemze R (2000). Primary and secondary cutaneous $\mathrm{CD}^{+} \mathrm{O}^{+}$lymphoproliferative disorders: A report from the Dutch Cutaneous 
Lymphoma Study Group and the long-term follow-up data of 219 patients and guidelines for diagnosis and treatment. Blood 95:3653-3661.

Davis TH, Morton CC, Miller-Cassman R, Balk SP, and Kadin ME (1992). Hodgkin's disease, lymphomatoid papulosis, and cutaneous T-cell lymphoma derived from a common T-cell clone. N Engl J Med 326:1115-1122.

de Bruin PC, Beljaards RC, van Heerde P, Van Der Valk P, Noorduyn LA, Van Krieken JH, Kluin-Nelemans JC, Willemze $\mathrm{R}$, and Meijer CJ (1993). Differences in clinical behaviour and immunophenotype between primary cutaneous and primary nodal anaplastic large cell lymphoma of T-cell or null cell phenotype. Histopathology 23:127-135.

Felgar RE, Macon WR, Kinney MC, Roberts S, Pasha T, and Salhany KE (1997). TIA-1 expression in lymphoid neoplasms: Identification of subsets with cytotoxic $\mathrm{T}$ lymphocyte or natural killer cell differentiation. Am J Pathol 150:1893-1900.

Foss HD, Reusch R, Demel G, Lenz G, Anagnostopoulos I, Hummel M, and Stein H (1999). Frequent expression of the B-cell-specific activator protein in Reed-Sternberg cells of classical Hodgkin's disease provides further evidence for its B-cell origin. Blood 94:3108-3113.

Kadin ME (1985). Common activated helper-T-cell origin for lymphomatoid papulosis, mycosis fungoides, and some types of Hodgkin's disease. Lancet 2:864-865.

Kadin ME (1991). Lymphomatoid papulosis, Ki-1+ lymphoma, and primary cutaneous Hodgkin's disease. Semin Dermatol 10:164-171.

Kadin ME, Drews R, Samel A, Gilchrist A, and Kocher O (2001). Hodgkin's lymphoma of T-cell type: Clonal association with a $\mathrm{CD}^{+} 0^{+}$cutaneous lymphoma. Hum Pathol 32: 1269-1272.

Kadin ME, Muramoto L, and Said J (1988). Expression of T-cell antigens on Reed-Sternberg cells in a subset of patients with nodular sclerosing and mixed cellularity Hodgkin's disease. Am J Pathol 130:345-353.

Kadin M, Nasu K, Sako D, Said J, and Vonderheid E (1985). Lymphomatoid papulosis: A cutaneous proliferation of activated helper T cells expressing Hodgkin's diseaseassociated antigens. Am J Pathol 119:315-325.

Kadin ME, Vonderheid EC, Sako D, Clayton LK, and Olbricht $S$ (1987). Clonal composition of T cells in lymphomatoid papulosis. Am J Pathol 126:13-17.

Kanzler H, Küppers R, Hansmann ML, and Rajewsky $\mathrm{K}$ (1996). Hodgkin and Reed-Sternberg cells in Hodgkin's disease represent the outgrowth of a dominant tumor clone derived from (crippled) germinal center B cells. J Exp Med 184:1495-1505.

Kaudewitz P, Stein H, Plewig G, Schwarting R, Gerdes J, Burg G, Kind P, Eckert F, and Braun-Falco O (1990). Hodgkin's disease followed by lymphomatoid papulosis: Immunophenotypic evidence for a close relationship between lymphomatoid papulosis and Hodgkin's disease. J Am Acad Dermatol 22:999-1006.

Krenacs L, Himmelmann AW, Quintanilla-Martinez L, Fest T, Riva A, Wellmann A, Bagdi E, Kehrl JH, Jaffe ES, and Raffeld $M$ (1998). Transcription factor B-cell-specific activator protein (BSAP) is differentially expressed in B cells and in subsets of B-cell lymphomas. Blood 92:1308-1316.

Krenacs L, Wellmann A, Sorbara L, Himmelmann AW, Bagdi E, Jaffe ES, and Raffeld M (1997). Cytotoxic cell antigen expression in anaplastic large cell lymphomas of T- and null-cell type and Hodgkin's disease: Evidence for distinct cellular origin. Blood 89:980-989.

Küppers R, Klein U, Hansmann ML, and Rajewsky K (1999). Mechanisms of disease: Cellular origin of human b-cell lymphomas. N Engl J Med 341:1520-1529.

Küppers R, Rajewsky K, Zhao M, Simons G, Laumann R, Fischer R, and Hansmann ML (1994). Hodgkin disease: Hodgkin and Reed-Sternberg cells picked from histological sections show clonal immunoglobulin gene rearrangements and appear to be derived from B cells at various stages of development. Proc Natl Acad Sci USA 91:10962-10966.

Küppers R, Zhao M, Hansmann ML, and Rajewsky K (1993). Tracing B cell development in human germinal centres by molecular analysis of single cells picked from histological sections. EMBO J 12:4955-4967.

Lukes RJ, Butler J, and Hicks EB (1966). Natural history of Hodgkins disease as related to its pathological picture. Cancer 19:317.

Marafioti T, Hummel M, Foss HD, Laumen H, Korbjuhn P, Anagnostopoulos I, Lammert H, Demel G, Theil J, Wirth T, and Stein H (2000). Hodgkin and Reed-Sternberg cells represent an expansion of a single clone originating from a germinal center B-cell with functional immunoglobulin gene rearrangements but defective immunoglobulin transcription. Blood 95:1443-1450.

Meggetto F, al Saati T, Rubin B, and Delsol G (1994). Lack of restricted $\mathrm{T}$-cell receptor beta-chain variable region ( $\mathrm{V}$ beta) usage of reactive T-lymphocytes in Hodgkin's disease. $\mathrm{Br} \mathrm{J}$ Haematol 86:524-532.

Müschen M, Küppers R, Spieker T, Bräuninger A, Rajewsky $\mathrm{K}$, and Hansmann ML (2001). Molecular single-cell analysis of Hodgkin- and Reed-Sternberg cells harboring unmutated immunoglobulin variable region genes. Lab Invest 81:289295.

Müschen M, Rajewsky K, Bräuninger A, Baur SB, Oudejans JJ, Roers A, Hansmann ML, and Küppers R (2000). Rare occurrence of classical Hodgkin's disease as a T cell lymphoma. J Exp Med 191:387-394.

Nutt SL, Heavey B, Rolink AG, and Busslinger M (1999). Commitment to the B-lymphoid lineage depends on the transcription factor Pax5. Nature 401:556-562.

Roers A, Montesinos-Rongen M, Hansmann ML, Rajewsky K, and Küppers R (1998). Amplification of TCRbeta gene rearrangements from micromanipulated single cells: $T$ cells rosetting around Hodgkin and Reed-Sternberg cells in Hodgkin's disease are polyclonal. Eur J Immunol 28:24242431.

Sanchez NP, Pittelkow MR, Muller SA, Banks PM, and Winkelmann RK (1983). The clinicopathologic spectrum of lymphomatoid papulosis: Study of 31 cases. J Am Acad Dermatol 8:81-94.

Seitz V, Hummel H, Marafioti T, Anagnostopoulos I, Assaf C, and Stein H (2000). Detection of clonal T-cell receptor gamma-chain gene rearrangements in Reed-Sternberg cells of classic Hodgkin disease. Blood 95:3020-3024.

Vergier B, Beylot-Barry M, Pulford K, Michel P, Bosq J, de Muret A, Beylot C, Delaunay MM, Avril MF, Dalac S, Bodemer C, Joly P, Groppi A, de Mascarel A, Bagot M, Mason DY, Wechsler J, and Merlio JP (1998). Statistical evaluation of diagnostic and prognostic features of $\mathrm{CD} \mathrm{O}^{+}$cutaneous 
lymphoproliferative disorders: A clinicopathologic study of 65 cases. Am J Surg Pathol 22:1192-1202.

Weiss LM, Strickler JG, Hu E, Warnke RA, and Sklar J (1986a). Immunoglobulin gene rearrangements in Hodgkin's disease [published erratum appears in Hum Pathol 1986 Nov;17(11):1106]. Hum Pathol 17:1009-1014.

Weiss LM, Wood GS, Trela M, Warnke RA, and Sklar J (1986b). Clonal T-cell populations in lymphomatoid papulosis: Evidence of a lymphoproliferative origin for a clinically benign disease. N Engl J Med 315:475-479.

White RM and Patterson JW (1985). Cutaneous involvement in Hodgkin's disease. Cancer 55:1136-1145.
Willemze R, Kerl H, Sterry W, Berti E, Cerroni L, Chimenti S, Diaz-Perez JL, Geerts ML, Goos M, Knobler R, Ralfkiaer E, Santucci M, Smith N, Wechsler J, van Vloten WA, and Meijer CJ (1997). EORTC classification for primary cutaneous lymphomas: A proposal from the Cutaneous Lymphoma Study Group of the European Organization for Research and Treatment of Cancer. Blood 90:354-371.

Willenbrock K, Roers A, Blöhbaum B, Rajewsky K, and Hansmann ML (2000). CD8 ${ }^{+}$T cells in Hodgkin's disease tumor tissue are a polyclonal population with limited clonal expansion but little evidence of selection by antigen. Am J Pathol 157:171-175.

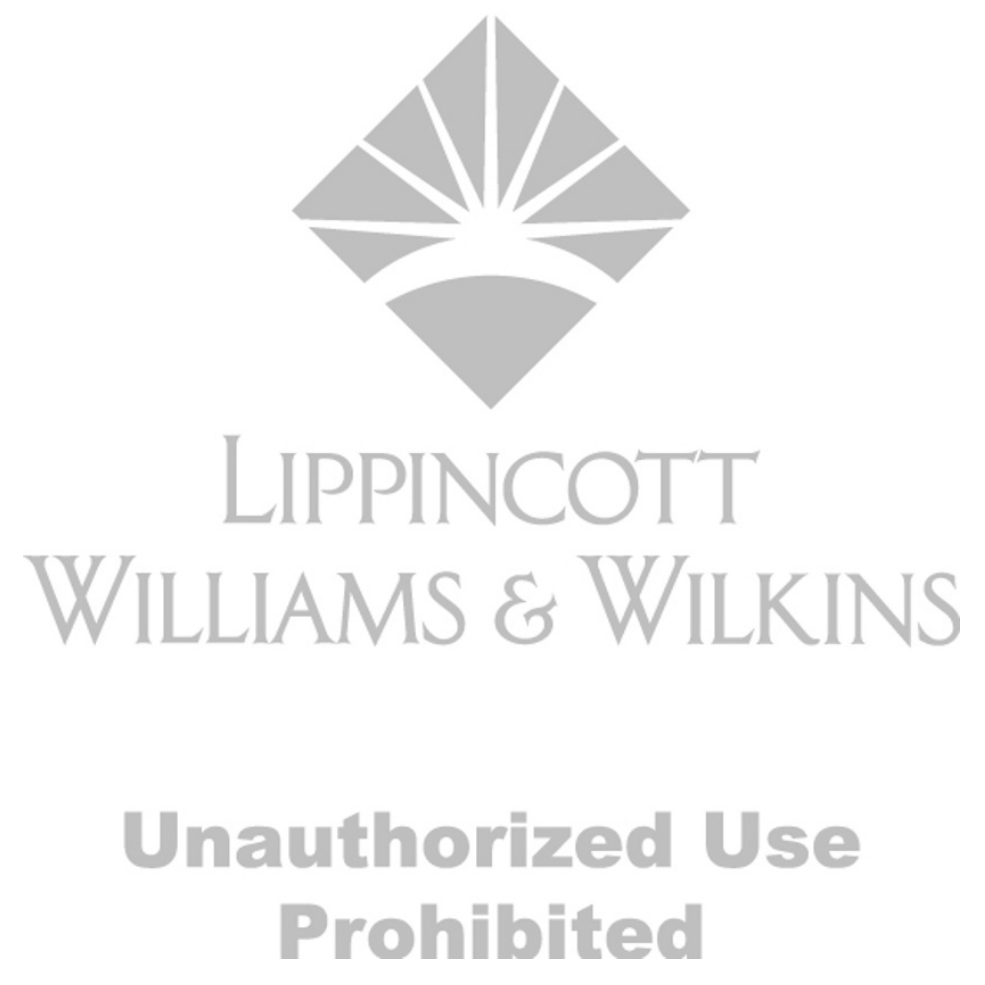

